\title{
MEMBANGUN MASYARAKAT DESA MELALUI \\ PEMBERDAYAAN EKONOMI DENGAN BUDIDAYA \\ TANAMAN PUCUK MERAH PADA UNIT USAHA BUMDES \\ DESA SEPOTONG
}

\author{
Irawan Fakhrudin Mahalizikri \\ Sekolah Tinggi Ilmu Ekonomi (STIE) Syariah Bengkalis \\ Email: irawanfma@gmail.com
}

\begin{abstract}
ABSTRAK
Pembangunan disektor fisik yang terus malaju seiring dengan pesatnya kemajuan ilmu pengetahuan dan teknologi perlu diimbangi dengan kemajuan masyarakat pada aspek nonfisik. Sejauh ini kemajuan ilmu pengetahuan dan teknologi masih menyisakan ketertinggalan masyarakat pada aspek nonfisik. Dunia pendidikan, kesehatan masyarakat, dan kesejahteraan masih jauh manjadi problem klasik yang butuh penanganan serius dari semua pihak. Perguruan Tinggi sangat berperan dalam ikut serta menyukseskan program pembangunan Nasional. Tujuan utama pembangunan Nasional adalah pembentukan masyarakat Indonesia yang modern namun tetap berpegang teguh pada Pancasila dan UUD 45. Dalam pembentukan masyarakat yang modern ini, perguruan tinggi bertugas menciptakan tenagatenaga ahli yang harus memiliki pengetahuan tinggi dan mampu mengembangkan ilmunya melalui teknologi yang akhirnya bisa dimanfaatkan oleh masyarakat Indonesia secara keseluruhan. Dengan mengikuti derap langkah pembangunan yang semakin dinamis untuk meningkatkan sumber daya manusia baik dalam pemamfaatan serta pengolahan sumber daya alam dan sumber daya manusia. Dalam mengimplementasikan keilmuan yang dimiliki dari berbagai disiplin ilmu yang untuk selanjutnya dapat diterapkan di tengah-tengah masyarakat khususnya desa Sepotong dalam memberdayakan salah satu unit potensi yakni tanaman pucuk merah.
\end{abstract}

Kata Kunci: Masyarakat Desa, Pemberdayaan Ekonomi, Desa Sepotong, Tanaman Pucuk Merah.

\section{PENDAHULUAN}

Pembangunan disektor fisik yang terus malaju seiring dengan pesatnya kemajuan ilmu pengetahuan dan teknologi perlu diimbangi dengan kemajuan masyarakat pada aspek nonfisik. Sejauh ini kemajuan ilmu pengetahuan dan teknologi masih menyisakan ketertinggalan masyarakat pada aspek nonfisik. Dunia pendidikan, kesehatan masyarakat, dan kesejahteraan masih jauh manjadi problem klasik yang butuh penanganan serius dari semua pihak. Perguruan Tinggi sangat berperan dalam ikut serta menyukseskan program pembangunan Nasional.

Tujuan utama pembangunan Nasional adalah pembentukan masyarakat Indonesia yang modern namun tetap berpegang teguh pada Pancasila dan UUD 45. Dalam pembentukan masyarakat yang modern ini, perguruan tinggi bertugas menciptakan tenaga-tenaga ahli yang harus memiliki pengetahuan tinggi dan mampu mengembangkan ilmunya melalui teknologi yang akhirnya bisa 
dimanfaatkan oleh masyarakat Indonesia secara keseluruhan. Hal tersebut biasanya disebut dengan Tri Darma Perguruan Tinggi ${ }^{1}$.

Di dalam hal ini Perguruan Tinggi kita kenal yang namanya Tri Darma Perguruan Tinggi, karena hal itu adalah tujuan dari didirikanya suatu perguruan tinggi, yaitu menciptakan lulusan mahasiswa yang berpendidikan, dan berguna tidak hanya untuk dirinya sendiri, namun juga berguna bagi masyarakat Indonesia. Bentuk nyata pengabdian seorang dosen berserta mahasiswa kepada masyarakat adalah dalam hal membantu perekonomian dan pemberdayaan masyarakat desa.

Secara langsung akan menunjukkan keterkaitan langsung antara dunia pendidikan dan upaya perwujudan kesejahteraan masyarakat. Beberapa aspek yang diperhatikan dalam penulisan dan potensi desa yang ada yakni berupa pengajaran, penelitan, dan pengabdian pada masyarakat. Yang kedua adalah pendekatan interdisipliner dan komprehensif yang bertolak dari permasalahan nyata masyarakat yang didekati dengan menggunakan segala ilmu pengetahuan, teknologi yang susah, sedang, dan atau akan dipelajari. Serta keberlanjutan dalam pengembangan yang bertumpu pada sumber daya lokal dan potensi yang ada pada desa tersebut.

Dengan mengikuti derap langkah pembangunan yang semakin dinamis untuk meningkatkan sumber daya manusia baik dalam pemamfaatan serta pengolahan sumber daya alam dan sumber daya manusia. Dalam mengimplementasikan keilmuan yang dimiliki dari berbagai disiplin ilmu yang untuk selanjutnya dapat diterapkan di tengah-tengah masyarakat khususnya desa Sepotong.

\section{HASIL DAN PEMBAHASAN}

Desa merupakan miniatur negara yang menjadi ujung tombak pembangunan, oleh karena itu pemerintah berharap supaya dapat menciptakan desa yang mandiri untuk itu perekonomian di prioritaskan sebagai kajian utama. Desa Sepotong merupakan salah satu wilayah administrasi Pemerintah Daerah Kabupaten Bengkalis Propinsi Riau di Kecamatan Siak Kecil. Dimana disebelah utara berbatasan dengan Desa Koto Raja, disebelah selatan berbatasan dengan Desa Langkat, sebelah barat pula berbatasan dengan Desa Lubuk Garam dan Lubuk Gaung Kecamatan Siak Kecil Kabupaten Bengkalis, sedangkan sebelah timur berbatasan Desa Laksamana dan Sungai Guntung Kecamatan Sabak Auh Kabupaten Siak.

Desa Sepotong ini terletak di: ${ }^{2}$

Provinsi : Riau

Kabupaten : : Bengkalis

Kecamatan : Siak Kecil

Kode Pos : 28716

Luas daerah $\quad: 10,25 \mathrm{Km} 2$

Jumlah Penduduk : : 1.209 jiwa

Dengan data desa sebagai berikut:

${ }^{1} \mathrm{http}: / /$ nofitahapsari.blogspot.co.id/2014/06/tridarmaperguruantinggi.html
${ }^{2}$ Dokumentasi: Monografi desa Sepotong Tahun 2016 
Lembaga Pemerintahan Daerah:

Jumlah Perangkat : 14 orang

Dusun : 3 buah

Rukun Warga : 6 buah

Rukun Tetangga : 13 Orang

Kelembagaan kemasyarakatan:

Organisasi perempuan : 2 kelompok

Organisasi laki-laki : 6 kelompok

Kelompok gotong royong : 13 kelompok

Lembaga adat : 1 kelompok

Lembaga Ekonomi:

BUMDES : 1 unit

UED - SP $\quad: 1$ unit

Kependudukan:

Rga : $387 \quad$ KK

Jumlah penduduk $\quad: 1.209$ jiwa

Penduduk berdasarkan jenis kelamin:

Laki-laki : 618 Orang

Perempuan : 591 Orang

Penduduk berdasarkan agama:

Islam $\quad: 1140$ Orang

Budha : 34 Orang

Penduduk berdasarkan suku:

Melayu : :190 Orang

Jawa : 947 Orang

China : 34 Orang

Batak :- Orang

Bugis :- Orang

Minang : 3 Orang

Lainnya : 9 Orang

Penduduk berdasarkan mata pencarian:

Petani : 730 orang

Perkebunan : :15 orang

Pedagang : :5 orang

Peternak : 12 orang

Pegawai Negeri Sipil : 12 orang

Honorer : 21 orang

Lainnya : 231 orang

Penduduk berdasarkan pendidikan:

Belum sekolah $\quad: 17$ orang 


$\begin{array}{ll}\text { SD/Sederajat } & : 127 \text { orang } \\ \text { SLTP/Sederajat } & : 93 \text { orang } \\ \text { SLTA/Sederajat } & : 63 \text { orang } \\ \text { Akademi/Sederajat } & : 58 \text { orang } \\ \text { D4/S1 } & : 24 \text { orang }\end{array}$

Penduduk berdasarkan umur:

0-4 tahun : 119 orang

5-9 tahun : 80 orang

10-14 tahun : 103 orang

15- 19 tahun : 107 orang

20-24 tahun : 109 orang

25-29 tahun : 75 orang

30-34 tahun : 116 orang

35-39 tahun :94 orang

40-44 tahun : 75 orang

45-49 tahun : 56 orang

50-54 tahun : 65 orang

54-59 tahun : 54 orang

60- 64 tahun : 39 orang

65-69 tahun : 23 orang

70-74 tahun : 24 orang

75 keatas : :29 orang

Sarana sosial pendidikan:

PAUD:

Jumlah sekolah : 1 buah

Jumlah murid : 9 orang

Jumlah guru / pengajar : : 3 orang

Prasarana fisik : 1 lokal

Taman kanak-kanak:

Jumlah sekolah $\quad: 2$ buah

Jumlah murid : 121 orang

Jumlah gurupengajar $\quad: 10$ orang

Prasarana fisik : 5 lokal

Sekolah Dasar (SD) Negeri:

Jumlah sekolah : 1 buah

Jumlah murid $\quad: 107$ orang

Jumlah guru/pengajar : : 15 orang

Prasarana fisik $\quad: 9$ buah

Perpustakaan : 1 buah

Madrasah ibtidaiyah:

Jumlah sekolah $\quad: 2$ buah

Jumlah murid : $: 82$ orang

Jumlah guru/pengajar : : 6 orang 
Prasarana fisik

Sarana rumah ibadah:

Masjid

Surau/langgar
: 6 lokal

: 4 buah

: 1 buah

Kebudayaan/kesenian :

Jumlah Perkumpulan Kebudayaan : 6 buah

Jumlah Sanggar Kesenian $\quad: 1$ buah

Sarana kesehatan:

Polindes

: 1 buah

Posyandu

: 2 buah

Bidan

: 1 orang

Dukun bayi

: 1 orang

\section{Sejarah dan Perkembangan Desa}

Desa Sepotong merupakan salah satu wilayah administrasi Pemerintah Daerah Kabupaten Bengkalis Propinsi Riau di Kecamatan Siak Kecil, Dimana disebelah Utara berbatasan Desa Koto Raja, di sebelah selatan berbatasan Desa Langkat, Sebelah Barat pula berbatasan dengan Desa Lubuk Garam dan Lubuk Gaung Kecamatan Siak Kecil Kabupaten Bengkalis, sedangkan sebelah timur berbatasan Desa Laksamana dan Sungai Guntung Kecamatan Sabak Auh Kabupaten Siak. Nama desa Sepotong ini berasal dari berbagai versi yang dijelaskan tetua terdahulu.

Menurut sejarahnya zaman dahulu kala ada sebuah kerajaan kecil yang berada di Sungai Gungtung atau Koto Raja, kerajaan ini di pimpin oleh seorang raja penyamun yang bernama Nya-nyau. Dalam kepemimpinannya raja tersebut kejam.Kerajaan ini sangat makmur dengan hasil buminya sehingga penduduknya makmur-makmur. Kerajaan berkembang dengan pesat sehingga terbentuknya suatu kota yang disebut dengan Koto Raja. Dalam kepemimpinannya raja tidak segan-segan memerintahkan algojonya untuk memancung orang, yang di rampok dan di ketahui bersalah atau berhianat kepada raja tersebut.

Sehingga tidak sedikit bangsa yang di rampok lalu di bunuh (di potong) oleh algojonya, lokasi exsekusi tidak jauh dari kerajaan sekitar lebih kurang $3 \mathrm{~km}$ dari sebelah barat kerajaan, yang berlokasi di sungai Sepotong. Dari tempat pemotongan itulah sampai sekarang di abadikan menjadi nama desa Sepotong. Namun kerajaan tersebut tidak meninggalkan bekas atau tanda-tanda kerajaan. Namun apabila ada orang yang tersesat di daerah pulau guntung tersebut akan ditemui puing-puing peninggalannya.

Ada juga yang berpendapat desa Sepotong pada masa dahulu kala sering banjir dan ada aliran air atau di sebut sebuah sungai buntu (yang sekarang berada di wilayah desa Lubuk Garam) kemudian sungai buntu tersebut di potong dengan penggalian parit menuju sungai Lubuk Gaung. Pemotongan parit antara sungai buntu menuju sungai lubuk gaung itulah menjadi dasar nama desa Sepotong. 


\section{Potensi Desa}

Desa Sepotong Kecamatan Siak Kecil Kabupaten Bengkalis banyak memiliki potensi yang masih belum terkelola dan membutuhkan sentuhansentuhan para pakar ahli. Untuk menggali dan mengolah potensi desa tersebut diperlukan dorongan dan perhatian dari pemerintah daerah untuk dapat membina dan mengembangkan potensi desa yang kemudian didapat skala prioritas untuk dikembangkan yang nantinya akan meningkatkan perekonomian masyarakat desa sehingga berdampak positif pada lingkungan sosial masyarakat jika kesejahteraan masyarakat dapat tercapai melalui pengelolaan potensi desa yang merata dan sistematis dan berkelanjutan.

Ada beberapa potensi desa yang dapat dikembangkan yang memiliki peluang cukup besar untuk dijadikan sebuah upaya peningkatan perekonomian desa diantaranya:

1. Usaha Mikro, Kecil dan Menengah

Masyarakat Desa sepotong banyak yang memiliki potensi sebagai wirausaha untuk Usaha Mikro, Kecil dan Menengah. Namun masyarakat setempat tidak banyak yang meiliki pengetahuan tentang pengelolaan UMKM tersebut secara benar sehingga banyaknya para pelaku usaha yang gagal dalam hal UMKM. Masyarakat masih perlu tambahan ilmu tentang pengelolaan UMKM agar potensi tersebut terkelola dengan baik.

2. Pertanian

Masyarakat desa Sepotong mayoritas mata pencahariannya adalah sebagai petani. Rata-rata masyarakat desa Sepotong baik laki- laki maupun perempuan tahu cara bertani dan berkebun. Salah satu potensi yang paling besar yang ada di desa Sepotong adalah dalam sektor pertanian. Pertanian yang dimaksud meliputi tanaman padi, sawit, karet dan sayuran. Pada umumnya masyarakat menjual hasil dari tanaman tersebut kepada tauke atau pemasok sawit. Sedangkan padi diproduksi namun hanya dikelola dan dikonsumsi sendiri. Apabila pemerintah setempat memperhatikan hal tersebut sangat sayang bahwa hasil pertanian padi dan sawit yang berpotensi sangat besar bagi pendapatan daerah ini tidak diperhatikan. Apalagi desa Sepotong ini merupakan sentral produksi padi terbesar diantara desa sekabupaten Bengkalis. Dimana didesa ini pun telah dibangun Rice Processing Complex (RPC) pada masa periode pemerintahan bupati yang telah lalu, namun tidak dimanfaatkan oleh pemerintah setempat sehingga terbengkalai.

3. Agro wisata

Menurut sudut pandang penulis bahwa desa Sepotong ini berpotensi untuk di jadikan agrowisata karena disini ada RPC (Rice Processing Complex) jika memang berjalan dan dikelola dengan baik, maka hal ini akan memberi nilai postif bagi pemerintah setempat dan desa Sepotong, contohnya hal tersebut akan mengundang wisatawan untuk melihat sendiri proses penggilingan padi secara berkualitas dan baik. Dimana RPC ini dibangun sangat luas dan besar satu satunya di Riau. Sebagaimana diketahui di Indonesia, daya tarik wisata sebagian besar masih berupa wisata bahari dan wisata budaya, sedangkan wisata berbasis perkebunan masih belum berkembang pesat karena kepemilikannya masih belum banyak. Namun setelah kami terjun kelapangan dan melihat sendiri kondisi yang ada didesa Sepotong ini memang dikenal akan hasil produksi pertanian nya yang cukup kaya. 


\section{Struktur Kepengurusan Desa}

Struktur kepengurusan desa Sepotong terdiri dari:

Kepala Desa

Sekretaris Desa

Staf

Kaur Pemerintahan

Kaur Pembangunan

Kaur Umum

Kaur Keuangan

Kaur Kemasyarakatan

Kepala Dusun Sri Damai

Kepala Dusun Sri Bangun

Kepala Dusun Sri Bangun Sari
: Isman S. Ag

: Edi Prayetno

: 1. Siswanto

2. Fahrizal

3. Septiliana

4. Selamat Hadi Prayetno

: Susilawati

: Zulfikar

: Suprianto

: Katmiatin

: Santoso

: Maftuh

: Jemari

: Juwair

\section{Penanaman Bibit Tanaman Pucuk Merah}

Penanaman bibit tanaman pucuk merah di sekitaran dusun Sri Damai tepatnya di sekitar lingkungan masjid Al-Falah dan kantor desa, di dusun Sri Bangun Sari tim kami menanam bibit tanaman pucuk merah di sekitar MDA dan masjid Al-Mukarramah juga di masjid Darussalam di dusun Sri Bangun Sari, terakhir kami menanam bibit tanaman pucuk merah di sekitar lingkungan masjid As-Shobrun. Jumlah seluruh bibit tanaman pucuk merah yang ditanami sekitar desa Sepotong berjumlah 40 bibit tanaman pucuk merah. Tujuan kami menanam tanaman pucuk merah di desa Sepotong adalah untuk penghijaun di sekitar tiaptiap dusun dan untuk meningkatkan pendapatan masyarakat dari budidaya tanaman pucuk merah yang memiliki keuntungan yang cukup besar apabila dibudidayakan dan didistribusikan dengan benar.

Faktor-faktor yang mendorong pelaksanaan penanaman bibit tanaman pucuk merah adalah:

1. Kerjasama Kelompok

Dengan jumlah anggota 8 orang dengan program studi yang berbeda namun tidak menjadi hambatan dalam berkerjasama. Justru secara bersama-sama menentukan kegiatan atau program kerja dapat terlaksanakan dengan baik. Semua berkat kekompakan dan kerjasama yang solid serta saling terbuka dan semua keputusan diambil berdasarkan mufakat dengan jalannya musyawarah.

2. Dukungan Aparatur Desa

Dukungan aparatur, warga dan tokoh-tokoh masyarakat dalam Kegiatan Kuliah Kerja Mahasiswa STIE Syariah tahun 2018 di desa Sepotong Kecamatan siak kecil Kabupaten Bengkalis merupakan faktor yang cukup dominan dalam menentukan beberapa keberhasilan dalam melaksanakan kegiatan kami dilapangan. Dukungan aparatur pemerintahan desa Sepotong merupakan akses dan pintu utama bagi kami dalam menjalankan kegiatan di desa Sepotong, karena berkat dukungan aparatur pemerintahan desa sebagai pihak berwenang yang memberikan status legalitaas pada kegiatan yang kami laksanakan di desa dapat berjalan dengan baik. 
3. Dukungan Masyarakat

Kelompok Kuliah Kerja Mahasiswa STIE Syariah Bengkalis tahun 2018 di desa Sepotong Kabupaten Bengkalis dalam merencanakan dan melaksanakan program kerjanya terbatas perannya sebagai konseptor dan fasilitator serta masyarakatlah yang lebih diutamakan karena masyarakat setempat lebih mengenal dan mengetahui akan kebutuhannya. Dan program kerja dapat terlaksana sesuai dengan kebutuhannya. Dan semua program kerja dapat terlaksana sesuai dukungan dan peran serta masyarakat secara langsung pada kegiatan KKM di desa Sepotong.

\section{Gambar 1}

\section{Penanaman Bibit Tanaman Pucuk Merah}

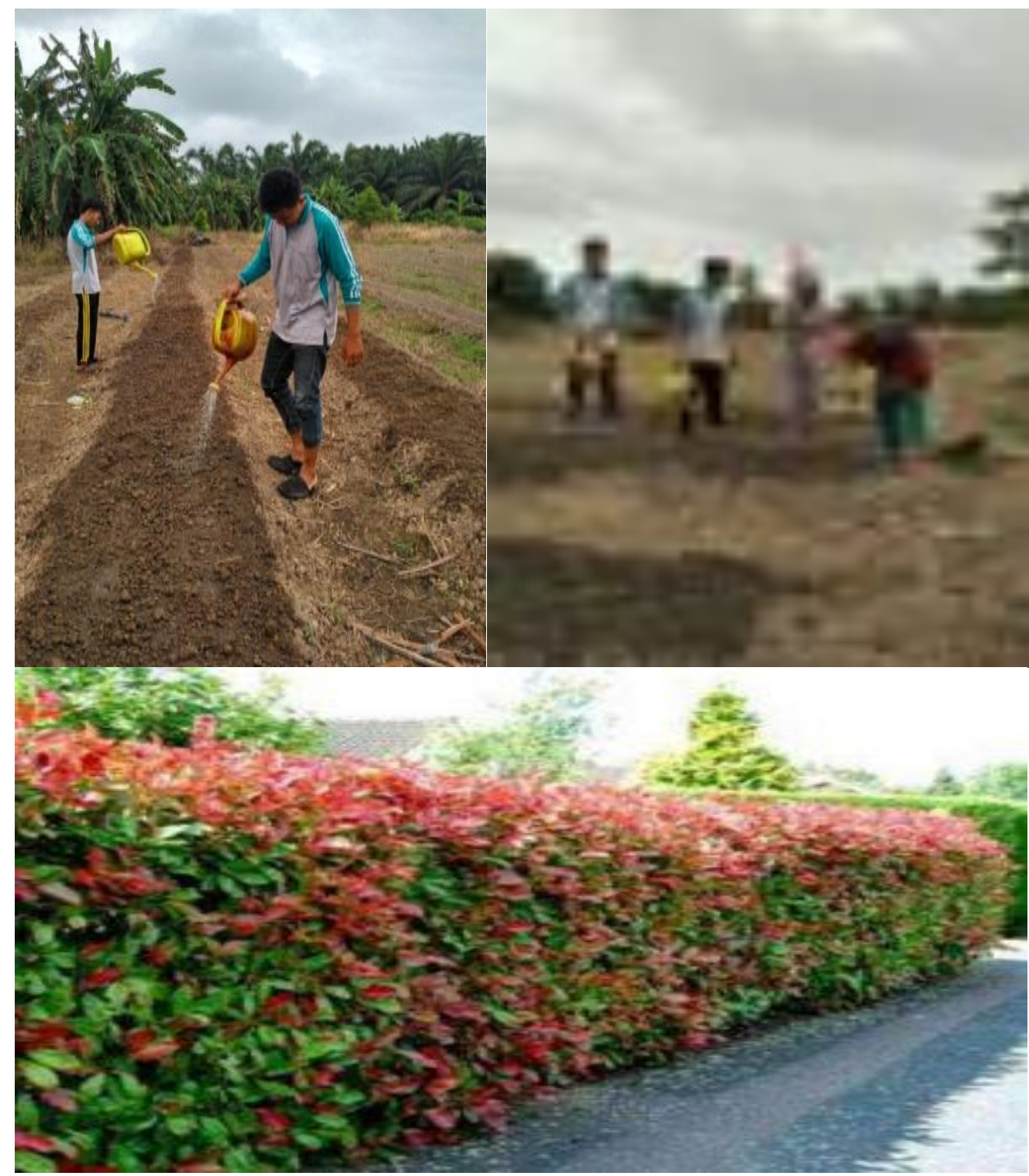

Tanaman pucuk merah dengan nama latinnya Syzygium Oleana yang saat ini sedang popular di Indonesia. Tanaman ini merupakan jenis tanaman perdu yang tergolong dalam tanaman hias yang banyak dijumpai di jalan, ditamantaman dan dipekarangan rumah. Hal ini dikarenakan tanaman ini sangat indah 
dengan daun muda pada pucuknya yang berwarna oren kemerahan, serta daun yang sudah tua berwarna hijau. Oleh sebab itulah tanaman ini dinamakan pucuk merah. Daun muda yang baru muncul seperti bunga diantara daun yang berwarna hijau.

Adapun Ciri-ciri tanaman pucuk merah antara lain adalah sebagai berikut:

1. Akar pada tanaman pucuk merah adalah akar tunggang yang merambat, berwarna coklat dan berbentuk bulat. Akar terus membesar sehingga dapat menopang pohon dengan kuat dan dapat berdiri tegak.

2. Batangnya berbentuk bulat dan berkayu, berwarna coklat dan memiliki kambium didalamnya. Batang tanaman ini dapat mencapai ketinggian lebih kurang 5-9 meter dan berdiameter 30-40 cm apabila terpelihara dengan baik dan tumbuh di tempat yang subur serta cukup nutrisi.

3. Daunnya berbentuk oval dan pada ujungnya berbentuk lancip. Struktur daunnya bertulang dan tumbuh pada tiap ranting pohon. Warna daunnya yang membuat pohon ini sangat indah di pandang mata yaitu, pada saat masih muda daun merwarna oren kemerahan, sementara daun yang telah tua berwarna hijau.

4. Bunga dari tanaman pucuk merah ini adalah bunga majemuk . Pada saat bunga mekar akan tampak kepala putik yang berwarna putih. Tangkai putiknya lebih pendek dibandingkan bunga dan benang sarinya. Tangkai sari berjumlah banyak dan berwarna putih.

5. Buah tanaman ini berbentuk bulat dan agak pipih, berukuran diameter lebih kurang 0,7 cm, dan berwarna hitam mengkilat bila sudah tua. Kemudian pada bagian tengah permukaan buah terdapat cekungan.

6. Biji tanaman pucuk merah berbentuk agak bulat dengan permukaan yang tidak rata. Warna biji coklat agak ungu dengan diameternya lebih kurang 3-4 mm.

7. Tanaman pucuk merah memerlukan penyinaran matahari sepanjang hari.

8. Tanaman pucuk merah dapat bertahan hidup dalam kurun waktu yang cukup lama.

Tanaman pucuk merah mempunyai banyak keistimewaan dan fungsi. Selain dari keindahannya yanga dapat dijadikan tanaman hias, tanaman pucuk merah yang kokoh dan menyimpan cadangan air dapat dijadikan sebagai tanaman penghijauan untuk mencegah tanah longsor. Dapat pula dijadikan pembatas dan pagar hidup, dan baik juga untuk merehabilitasi lahan.

\section{Cara Budidaya Tanaman Pucuk Merah}

Tanaman pucuk merah dapat diperbanyak dengan 2 cara, yaitu cara generatif (dari bijinya) dan cara vegetatif (stek). Pada kesempatan kali ini akan dibahas tentang memperbanyak tanaman pucuk merah dengan cara vegetatif atau stek, yang pada prinsipnya sama dengan cara stek bunga mawar dan cara menanam bunga nusa indah. Berikut langkah-langkah cara stek pucuk merah:

1. Mempersiapkan Bibit Tanaman

Untuk mendapatkan hasil tanaman pucuk merah yang baik dan kuat, pemilihan bibit harus menjadi prioritas utama. Beberapa langkah dalam mempersiapkan bibit tanaman:

- Untuk bibit tanaman pucuk merah, pilihlah batang yang tidak terlalu tua dan tidak terlalu muda. Pilihlah batang dari pohon yang sehat dan kuat. 
- Gunakan pisau yang tajam dan steril untuk memotong batang tanaman sepanjanglebih kurang 20-25 cm.

- Jika batang memiliki banyak daun maka buanglah daun - daunnya dan sisakan 2-3 helai daun muda saja yang ada dipucuknya

- Setelah itu runcingkanlah bagian bawah batang, kemudian rendam kedalam larutan fungisida yang berdosis rendah selama lebih kurang 510 menit.

- Angkat batang tersebut lalu keringkan dengan cara mengangin anginkan.

2. Mempersiapkan Media Tanam

Sebelum melakukan penyetekan, sebaiknya kita mempersiapkan media tanamnya terlebih dahulu seperti cara menanam bunga chrysanthemum dan cara menanam bunga violet. Berikut beberapa langkah dalam mempersiapkan media tanam:

- Persiapkan media tanam berupa tanah yang subur yang telah dicampur dengan pupuk kandang dengan perbandingan 1:1.

- Kemudian siapkan polybag atau pot yang telah dilubangi pada bagian dasarnya untuk memudahkan keluar masuknya air agar batang tidak busuk.

- Tuangkan tanah yang telah dicampur pupuk ke dalam polybag, kemudian padatkan dan ratakan.

- Setelah itu diamkan media tanam lebih kurang selama 1 minggu agar pupuk dan tanah dapat menyatu dengan sempurna.

3. Melakukan Penanaman Bibit Stek ke Media Tanam

Selanjutnya yang kita lakukan adalah menanam bibit stek ke media tanam yang telah kita persiapkan sebelumnya. Ikuti langkah-langkah dibawah ini:

- Oleskan hormon auksin pada ujung batang stek yang telah diruncingkan.

- Kemudian buatlah lubang pada media tanam polybag sedalam lebih kurang 0,5-1 cm.

- Lalu tanam batang stek yang telah diberi hormon auksin ke dalam polybag media tanam, kemudian tutup lubang dan ratakan.

- Siram polybag yang sudah ditanami dengan air sampai air siramannya keluar dari lubang polybag.

- Letakkan polybag di tempat yang teduh, tidak terkena matahari secara langsung dan air hujan.

- Siramlah tanaman secara rutin 2 kali sehari pada waktu pagi dan sore hari.

- Pindahkan polybag ke tempat yang lebih terbuka dan mendapatkan sinar matahari langsung setelah berusia lebih kurang 2 minggu.

4. Melakukan Penanaman ke Lahan Tanam

Setelah tanaman stek berusia lebih kurang 2 bulan, maka waktunya untuk memindahkan ke lahan tanam dengan cara berikut:

○ Lokasi tanam yang baik adalah yang terkena sinar matahari penuh sepanjang hari, karena tanaman pucuk merah memerlukan sinar matahari yang cukup.

- Setelah anda menemukan lokasi tanam yang cocok, kemudian buatlah lubang sedalam 30x30x30 cm. 
- Campur pupuk kandang yang telah kering dan tanah galian dengan pebandingan 2:1, kemudian masukkan kedalam lubang lebih kurang tingginya $2 / 3$.

- Ambillah bibit stek yang telah kita buat tadi, pilih yang daunnya mengkilap dan batangnya sudah kokoh.

- Bukalah plastik polybag perlahan-lahan, jangan sampai merusak akar tanaman.

- Kemudian letakkan ke dalam lubang, dan timbun dengan sisa tanah galian yang telah dicampur dengan pupuk kandang.

- Setelah selesai, siramlah dengan air secukupnya dan jangan sampai air tergenang.

5. Melakukan Perawatan

Setelah selesai melakukan penanaman, berikutnya adalah melakukan perawatan. Beberapa perawatan yang harus dilakukan adalah penyiraman, pemupukan, dan pemangkasan.

\section{Faktor Penghambat Budidaya Tanaman Pucuk Merah:}

1. Tanaman pucuk merah merupakan produk baru, serta proses penjualannya kurang jelas sehingga masyarakat disana banyak lebih memilih pekerjaannya sendiri yang sudah turun temurun dan menghasilkan yaitu menanam palawija seperti sawit dan bertani padi dibandingkan untuk menanam jenis tanaman lainnya seperti tanaman pucuk merah yang mereka anggap baru. Yang mana faktor dominan dari pendapatan masyarakat disana memang dari hasil sawit dan padi yang jumlahnya lebih maksimal dan menjanjikan. Sehingga mereka agak sulit untuk memberi waktu terhadap kegiatan yang diselenggarakan untuk potensi desa yang baru dalam hal ini dianggap karena kurang menjanjikan dikarenakan dianggap barang baru dan pemasarannya yang belum jelas..

2. Cuaca yang beberapa waktu terakhir masa kami mengabdi lebih sering hujan hingga menyebabkan tertundanya kegiatan sehingga harus dilaksanakan diwaktu-waktu terakhir sampai pada ssat penyepakan dan proses penjualan

\section{KESIMPULAN}

Berdasarkan hasil pengamatan dan analisa kami di desa Sepotong kecamatan Siak Kecil kabupaten Bengkalis selama 2 bulan dapat disimpulkan sebagai berikut:

1. Masih banyak permasalaha-permasalahan yang harus diselesaikan dalam upaya membangun dan menggali serta mengolah potensi-potensi yang masih banyak terdapat di daerah perdesaan khususnya dalam pengelolaan UMKM terutama potensi pucuk merah yang tengah di gagas.

2. Dalam mengolah potensi tersebut masih diperlukan perhatian dari pemerintah daerah Kabupaten Bengkalis untuk menindak lanjuti temuan-temuan kelompok Kuliah Kerja Mahasiswa sebagai masukan dan acuan dalam melaksanakan pemerataan ekonomi.

3. Banyak masyarakat desa Sepotong yang sebenarnya masih kesulitan dalam hasil pengolahan pertanian sehingga sebenarnya bukan tak berminat tetapi 
kurangnya pemahaman dan pengetahuan masyarakat terhadap pengolahan dan pendistribusian hasil pertanian.

\section{DAFTAR PUSTAKA}

Helmi, A. F. 2016. Ekstrak Daun Pucuk Merah (Syzygium Oleana) Sebagai Inhibitor Korosi Baja St.37 Dalam Medium Asam Klorida. Skripsi Universitas Andalas Padang: Tidak Diterbitkan

Ibrahim dan Hizqiyah. 2013. Dasar-Dasar Fisiologi Tumbuhan. Bandung: Pelangi Press

Mansur, I. 2015. Bisnis dan Budidaya 18 Kayu Komersial. Cetakan pertama. Jakarta: Penebar Swadaya.

Pedoman Laporan KKM STIE Syariah Bengkalis

Dokumentasi: Monografi Desa Sepotong Tahun 2016

http://nofitahapsari.blogspot.com/2014/06/makalah-tri-darma-perguruantinggi.html 